\title{
An Instructional Planning and Implementation of a Museum Tour Addressing Multiple Intelligences for First Graders
}

\author{
Nida Temiz* \\ Department of Primary Education, Başkent University, Ankara, Turkey
}

ORCID: 0000-0003-4081-0115

Article history

Received:

15.10.2020

Received in revised form:

27.12.2020

Accepted:

12.01.2021

Key words:

Museum education;

Instructional planning;

Primary education
Contemporary museums are not only places where collections are protected and exhibited; they are also effective and efficient learning and teaching environments. However, both contemporary and traditional museums need to be improved in terms of their educational functions. This study planned and implemented a museum tour addressing multiple intelligences for first graders at primary school with the purpose of demonstrating an effective museum tour. The convenience sampling method was used for determining the participants of the study. The researcher, together with 5 primary school teachers, 120 first-grade students and 44 undergraduates from the Department of Primary Education at the Faculty of Education participated in the study. This study was designed as action research, which is one of the qualitative research designs. Data were collected using semi-structured interviews, observations, and student-recalled questionnaires. The study showed that the teachers' and the undergraduates' thoughts about the planning and implementation were mostly positive, especially in terms of students' motivation, detail planning and the undergraduates' role of the implementation as qualified staff. Moreover, the findings related to the students' learning indicated that it was stored in their long-term memory. As a result of the study, the museum tour plan addressing multiple intelligences for first graders will be an example of effective museum education for teachers and museum educators in various ways.

\section{Introduction}

Museums continue to exist from the past to the present but are also developing depending on the opportunities offered by science and technology of the current era and what that era requires. These developments affect the objectives, structure, and function of museums. In this regard, museums are much more than places where collections and works of art are simply protected and exhibited. Similarly, the role of the museum visitor has altered and it is no more perceived as inferior to those of an observer and researcher. On this topic, Karadeniz, Artar, and Çakır İlhan (2015) stated that museum visitors have been positioned in the centre rather than constituting a place where viewers examine the museum collection, observers and researchers study on a subject of expertise. Accordingly, they drew attention to

\footnotetext{
* Correspondency: ntemiz@baskent.edu.tr
} 
the fact that museums have been turning into educational centres having contemporary structure and sensory as well as a synergistic atmosphere. Visitors could learn by having fun at museums.

Museums have various functions according to the reasons for their establishment, and they also share common purposes: one of those purposes is education (Ayaydin, 2017). Worldfamous museums increasingly prioritise their educational function. Buyurgan (2017) stated that there are educational units with specialist staff in museums in Germany, England, France, and the United States, and they serve as both schools and mobile museums. Additionally, Buyurgan (2017) emphasised that internationally renowned and valuable museums such as the British Museum and the Louvre also offer services for schools, teachers, and students.

Although educational function of museums is somewhat understood, there have also been a small number of museums around the world that do not limit their educational functions to children having school visits. One of them is Australian Museum, which is the oldest museum in Australia and one of the oldest in the world. Dockett, Main, and Kelly (2011) stated that Australian Museum has provided a play/learning space developed specifically for children aged from birth to five years since 1999, which was realized by consulting with parents, educators, academicians and community organizations. The space was called "Kids' Island" and designed to reflect roles and purposes of the museum via creating a play-based learning environment. In 2006-2007, the space was replaced by another space for children as a part of redevelopment of the museum. The new place was named Kidspace. It was important to underline the fact that children views via a research project conducted by Dockett et al. (2011) for the development of the new space were taken into account. the research project showed that the museum was advanced enough to not only offer children-friendly learning spaces in museums, but also to understand the importance of developing such areas by getting children's views.

When we look at the literature on museum education in Turkey, museums seemed to have received less attention than they actually deserved as educational spaces till 1990's in Turkey. In Turkey, the Museums Internal Services Regulation came into force with the approval of the Ministry Authority on 30 April 1990 and numbered 1578. Under this regulation a museum is defined as:

a permanent institution that determines and reveals; examines, evaluates, protects and promotes cultural assets by using scientific methods; displays them constantly and temporarily; enhances the public's education in the field of cultural and natural assets; and is effective in developing a world view (The Ministry of Culture and Tourism, 2020 please state the relevant page number)

Moreover, various functions of museums were listed within the scope of this definition of a museum specified in the regulation. One of them was 'educational courses, conferences, trips are organised in and out of the museum.' However, we encounter opinions and research results indicating that we-as Turkish people- are not that good at museum education. In this regard, Akman, Altınkaynak, Özen Altınkaynak Ertürk, Ertürk Kara, and Can (2015) stated that museum education was limited to 'museum weeks' and traditional museum trips, so it was difficult to talk about planned and systematic practices in Turkey related to museum studies and museum visits. In addition to this, they emphasised that there were no experts in the field of museum pedagogy in most of the museums and educational institutions. Consequently, the educational function of museums was weak because of this limitation. 
Buyurgan (2017) drew attention to the scarcity of educational units, workshops, activities, or services within museums in Turkey. Moreover, she emphasised that most of the teacher education programmes do not include a course on museum education, so she has been conducting studies with the purpose of being a guide on how to create an effective and efficient museum visit for teachers. Buyurgan (2017) also expressed that the number of education departments in museums is gradually increasing but these are not yet sufficient in Turkey. In addition, she cited the Anatolian Civilizations Museum, the Rahmi M. Koç Museum, the MTA Museum of Natural History, and the Sakip Sabanci Museum as examples of museums in Turkey offering various services for schools, teachers and students.

It was clear that there were valuable initiatives in Turkey in terms of museum education but these are still not enough especially when considering that research studies showed positive implications of museums, museum education, museum tours on educational field. When we look at the findings of such research studies, the results of them indicated museums tours provide meaningful, permanent learning opportunities for the relevant parties. For example, Anderson, Piscitelli, Weier, Everett, and Tayler (2002) conducted a research study in four different museum environments: a natural and social history museum, an art gallery, a science center, and a hybrid art/social history museum. Their participants were four-to-seven-year-old 99 children. They carried out a ten-week, multi-visit museum program with the children, then interviewed them to probe the saliency of their experiences and the ways in which they came to understand the museums they visited. The findings of the study showed that museum-based exhibits and programmatic experiences placed within children's world context such as play, and stories offered had more impact and more meaningful than museum experiences far from a child's world context. They concluded that museum experiences embedded in children's familiar socio-cultural context were influential mediators of learning and memory.

Another related research was conducted by Wolins, Jensen, and Ulzheimer (1992) with the basic research question "What do children remember about their museum visits, and why?" The purpose of the study was to understand what third-grade students remembered about the museum field trips they had taken during the year. The findings of the study showed that grouping of several dynamics explained which museum trips the students remembered and there were three factors appeared across cases:

1. high personal involvement (positive or negative) for an individual child (as opposed to the whole class)

2. links with the curriculum (when the teacher embellished the unit with many varied classroom activities)

3. multiple or repeat visits to the same institution.

When these three conditions were present, children re-called that specific trip quickly and provided elaborate descriptions of their experience, including objects they encountered, facts they recalled, and activities in which they were engaged. (Wolins, Jensen,\& Ulzheimmer, 1992, p. 25)

F. Erbay (2017) stated that museums have become places where educational and instructional activities are carried out in addition to continuing their existing functions: in the twenty-first century, museum visitors have turned into active participants. M. Erbay (2017) stated that museums should be open to innovations and should move with the times in order to perform their educational functions. That requirement indicated that museum presentations turned from ones with classical stability to dynamic creativity. At this point, M. Erbay (2017) stated that museums could perform their educational functions through new teaching methods and 
techniques.

According to MIT (please state the full form i.e. "Multiple Intelligences Theory" first rather than the acronym), the students have their own, unique multiple intelligences profile comprising dominant and non-dominant intelligences so using more than one teaching method and activity together (in an eclectic fashion) throughout instruction enable students to learn better. Hence referring to teaching methods and activities addressing their dominant intelligences and to strengthen their non-dominant intelligences by employing teaching methods and activities addressing their non-dominant intelligences is useful. As a result, MIT indicated that instruction should include various teaching methods and activities together. In this context, a museum tour was planned using eclectic teaching methods and activities (viz. question and answer, out-of-class activities, storifying, visual expression, verbal expression and others) as indicated by multiple intelligences theory (MIT). Moreover, Ayaydin (2017) emphasised that MIT values individual differences and puts forward student-centred education for museum education.

\section{Multiple intelligences theory}

The theory of multiple intelligences was proposed by Howard Gardner in 1983. The theory is about human cognition and Shearer (2020) expressed that MIT was one of the intelligence theories based on neural evidence. Moreover, MIT has been accepted and its implications on learning and teaching have found approval from the field of education. The reason for this, as Gouws (2007) explained, is that educators have always been aware of individual differences in terms of learning.

The eight intelligences can be briefly described as verbal-linguistic intelligence, the ability to express oneself or to produce ideas using language and words (Brualdi, 1998); mathematicallogical intelligence, the ability to think and reason logically and to use numbers (Nolen, 2003); visual-spatial intelligence, the ability to think spatially, read and understand visual materials, such as maps, and to express oneself visually; musical-rhythmic intelligence, the ability to comprehend and compose musical pitches, tones and rhythms (Brualdi, 1998); bodily-kinaesthetic intelligence, the ability to produce something or solve problems using one's physicality (Gardner 1993); interpersonal intelligence, the ability to socialise, cooperate, and deal well with others and to understand their motivations (Gregg, 1997); intrapersonal intelligence, the ability to know and understand oneself (Sternberg, 2003); and lastly, naturalistic intelligence, the ability to respect and understand nature (Nolen, 2003).

\section{Purpose of the study}

This study planned and implemented a museum tour addressing multiple intelligences for first graders with the co-operation of undergraduates from the Department of Primary Education to demonstrate an effective museum tour plan.

The purpose of the study was to explore the primary school teachers' and the undergraduates' thoughts about the museum tour addressing multiple intelligences in terms of planning and implementation and to find out the students' levels of recalling the learning from the museum tour. The following research questions guided the study:

(1) What do the teachers think about the museum tour addressing multiple intelligences in terms of planning and implementation of the plan and the students' learning and recall? 
(2) What do the undergraduates think about the museum tour addressing multiple intelligences in terms of the planning, implementation, and the students' learning?

(3) Do the students remember what they learned throughout the museum tour one year after the implementation of the museum tour?

\section{Method}

\section{Design of the study}

Action research is also known as the research is generally conducted by teacher researchers. Action research is defined as follows,

Action research is any systematic inquiry conducted by teacher researchers, principals, school counselors, or other stakeholders in the teaching/learning environment, to gather information about the ways that their particular school operate, how they teach, and how well their students learn. This information is gathered with the goals of gaining insight, developing reflective practice, effecting positive changes in the school environment (and on educational practices in general), and improving student outcomes and the lives of those involved. (Mills, 2000, p.6)

The current research with the purpose of demonstrating an effective museum tour and the research questions require such a research design defined by Mills (2000) especially in terms of planning, implementing, and students' learning. In this regard, the researcher's role in the current study was acting as a participant observer, team leader, school counselor and teacher.

Besides, Berg (2001) said one of the primary tasks of action research was uncovering or producing information and knowledge that would be openly functional to a group of people through research, education, and socio-political action. In this respect, the present study provides information and knowledge for primary education teachers in terms of planning and implementing effective contemporary museum tours by presenting an example. Therefore, the research was designed as action research, which is one of the qualitative research designs.

\section{Ethical considerations}

The researcher provided educational and instructional consultancy services to the school in the study. Therefore, the school administration supported the research and gave the researcher permission to conduct the study. Furthermore, official permission from Başkent University was granted in order to visit the Başkent University Abdürrahim Tuncak Atatürk Museum. The participant teachers and undergraduates were informed that they had the option of withdrawing from the study at any time. In order to ensure confidentiality for the participant teachers, undergraduates, students and school codenames have been used in transcriptions, field notes and the final report.

\section{Participants of the study}

The researcher was an instructor at the Department of Primary Education at one university and a supervisor for some primary schools in Ankara. The first-grade students and their teachers were selected as participants from one of the private primary schools where the researcher was a supervisor. The undergraduates were the researcher's students from the university. Therefore, the sampling method used for determining the participants of the study was convenience sampling. The school had 5 first grade classes with 120 students and 5 
teachers: all of them participated in the study. All the participant teachers were female and their educational level and years of experience were presented in the Table 1. From the university, 44 third-year undergraduates from the Department of Primary Education voluntarily participated in the study.

Table 1. The teachers' years of experience, level of education.

\begin{tabular}{llll}
\hline Teacher code & Level of education & $\begin{array}{l}\text { Years of experience (as } \\
\text { a teacher) }\end{array}$ & $\begin{array}{l}\text { Years of experience (as } \\
\text { private primary school } \\
\text { teacher) }\end{array}$ \\
\hline TA & Bachelor & 3 & 3 \\
TB & Master & 6 & 6 \\
TC & Master & 15 & 12 \\
TD & Master & 15 & 12 \\
TE & Bachelor & 7 & 7 \\
\hline
\end{tabular}

The researcher was the planner, implementer, teacher, group leader and trainer throughout the study. In detail, the researcher planned the museum tour addressing multiple intelligences and led the implementation of the plan. The first-grade students knew the researcher, and they treated the researcher like their teacher because the researcher had conducted various studies with them previously. Moreover, the undergraduates knew the researcher as their tutor. The researcher was the group leader and trainer for the undergraduates. The researcher was involved in all the stages of the museum tour and interacted with all the participants of the study, so the researcher's varying roles was one of the primary reasons for the study to be an action research.

\section{Overall research procedure}

The research process was carried out in the following steps:

(1) Determining the museum with the primary education teachers in light of the learning outcomes and units of the first-grade social studies course.

(2) Obtaining the necessary official permissions from Başkent University for the museum tour.

(3) Visiting the Başkent University Abdürrahim Tuncak Atatürk Museum and getting information about the museum with the participant undergraduates.

(4) Planning the museum tour addressing multiple intelligences for the first graders. The plan developed by the researcher for the study is presented under the sub-title "The plan."

(5) Training the undergraduates through MIT, excursion observation teaching method and museum education.

(6) Preparing the equipment and materials necessary for implementing the museum tour plan by the undergraduates under the leadership of the researcher.

(7) Implementing the plan with two classes between 10:00 a.m. and 12:00 p.m., and three classes between 1:00 p.m. and 3:00 p.m. on one day (21 November 2018).

(8) Conducting group interviews with ten undergraduates after the implementation.

(9) Taking written notes via abbreviations, video recording them and transcribing them on the same day as the recording in order to avoid data loss.

(10) Taking the participant teachers' views after the implementation.

(11) Implementing recall questionnaires with the participant students 11 months after the implementation. 


\section{The plan}

The researcher's plan comprised four sections, namely (1) instruction identity, (2) orientation, (3) achievement, and (4) transfer and evaluation. The definitions of the sections and the activities of the sections as follows:

(1) Instruction identity: This section included information about team members, the target population, duration of museum visit, the materials, the intended learning outcomes, the implementation of the museum tour, permission procedure for the museum tour and groundwork for the implementation.

The team members: 5 teachers, 44 undergraduates

The researcher was assisted by 4 undergraduates who did not take over the responsibility of any first-grade students. The remaining 40 undergraduates were responsible for the students as though they were educationally qualified museum staff and teachers. Each undergraduate were responsible for three students.

Target population: The first graders were divided into two groups. The first group comprised 48 students; the second group comprised 72 students. In total there were 120 first graders.

Duration: Each group of students spent two hours in the museum.

Intended learning outcomes:

- The students had knowledge about one of the houses Mustafa Kemal Atatürk lived in.

- The students had knowledge about one of the objects in the museum that belonged to Mustafa Kemal Atatürk

- The students had knowledge about at least one object that belonged to Mustafa Kemal Atatürk

Materials: 120 envelopes, photographs of objects that belonged to Mustafa Kemal Atatürk. Rope, puncher, scissor.

Preparation for orientation: the photographs of the objects displayed in the museum were put in the envelopes, one for each envelope. The envelopes were hung on trees around the museum before the students came to the museum.

Permission: Taking permission from the district directorate national education under the responsibility of the school and the teachers. The school got an appointment from Başkent University for the museum tour.

The Museum:

Abdürrahim Tuncak is the adopted son of Atatürk. Mr. Tuncak donated many items inherited from Atatürk to state museums. Moreover, Mr. Tuncak donated many original photographs to Başkent University where he was received as an honoured guest and he excitedly witnessed improvements. The university decided to construct a museum to honour Mr. Tuncak's memory. Thus, the museum was constituted on 10 November 1996 and photographs and other objects have been exhibited at Başkent University Abdürrahim Tuncak Atatürk Museum since 8 October 1998.

This building is a reproduction of the house Atatürk first kept when he migrated from Thessaloniki to Istanbul with his family. In this house, Atatürk; his mother Zübeyde Hanim; his sister Makbule (Atadan) Hanim; her adopted son Abdürrahim (Tuncak) Bey; and the housekeeper, whom Abdürrahim Bey referred to as 'Ayşe Abla', lived from 1912-1919 at Akaretler in Istanbul.

In the museum, 213 negative films, 143 framed photo albums and 32 different types of objects, all belonging to Atatürk and Zübeyde Hanim are displayed. Among these items are the prayer rug used by Zübeyde Hanim; the Quran that Atatürk read; the suitcases, clothes and coffee cups used by Atatürk; barbecue and the like. In addition, a cow statue 
symbolising the cow named Bahtiyar, which Mr. Abdürrahim Tuncak regarded as one of the main assets of the house, was also exhibited in the garden.

Note: The activities starting from the section of orientation and ending with the section of transfer and evaluation addresses as many intelligences as possible.

The multiple intelligences addressed by the activities are expressed in the brackets via abbreviations. $\mathrm{L}$ is for verbal-linguistic intelligence; $\mathrm{ML}$ is for mathematical-logical intelligence; VS is for visual-spatial intelligence; MR is for musical-rhythmical intelligence; INTER is interpersonal intelligence; INTRA is intrapersonal intelligence; and $\mathrm{N}$ is for naturalistic intelligence.

(2) Orientation: The section included in-museum activities to arouse the students' interest and motivate them.

Orientation Activity (L-INTRA-N): The students were welcomed and asked to gather around the researcher. The researcher introduced herself as the museum tour leader. The researcher stated that they will play a joyful activity and asked them to look at the environment, to see the envelopes, which are the materials of the activity. Then the researcher gave information about the museum (L). The content of the information included Atatürk's love for children because Atatürk lived with his adopted child, Abdurrahim in the house (INTRA) and Atatürk's love for animals because the cow named Bahtiyar lived with them in the house $(\mathrm{N})$.

(3)Achievement: The section consisted of in-museum activities with the aim of letting the students achieve the intended learning outcomes.

Achievement Activity (VS-L-BK-INTER-INTRA): The researcher and the four undergraduates assisted the researcher in dividing the students into groups of three. Then each of the 40 undergraduates took one group composed of three students each. The researcher introduced the undergraduates to the students as their museum teacher. The researcher gave them five minutes to get acquainted. The researcher emphasised each group is a team with their museum teacher (INTER). Then the researcher counted up to three. Then, the students ran around to take one envelope and come back to see their museum teacher (BK). The students opened their envelope. Their mission was to find the photograph from the envelope in the museum with the help of their group members (VS). The groups with their group leader visited the museum beginning with the first floor of the museum building and ending with the last floor (BK). During the visit they were also trying to find the photograph from their envelope. When they found the photograph (VS), they read the information about it and asked the group leader to learn that information (L). After that, each group member shared the information about the photograph with the other members of the group with the help of the group leader (INTER).

(4)Transfer and evaluation: The section compares activities to ensure the students' learning.

Transfer and evaluation activity (VS-L-INTRA-INTER): The students with their group teacher exited the museum. The researcher, as their museum leader, asked the students to state their opinion about the museum tour or ask questions (INTER). After taking their opinions and questions, the researcher and the group leader teachers said goodbye. When the students returned to their school, their teachers talked with them about the museum tour and they participated in various activities. Lastly, the students filled in the recall questionnaire prepared by the researcher 11 months after the museum tour. The questionnaire included questions related with photographs they studied, knowledge they gained from the tour and feelings they had during the tour (VS-L-INTRA).

\section{Data collection methods and instruments}

The data were collected through interviews, observations, and student recall questionnaires. Two semi-structured interview instruments were developed by the researcher: one was for the participant teachers, and the other was for the participant undergraduates. 
The main focuses of the interview instruments were constructed in light of the research questions of the study. The focuses of the interview instrument prepared for the teachers were as follows:

(1) Planning (comparison of ordinary and the current study's plans; thoughts about sections and details of the plan made for the current study)

(2) Implementation (thoughts about implementation of the plan in terms of each section (orientation, achievement, transfer and evaluation); thoughts about the points of the implementation in terms of essentiality)

The focuses of the interview instrument prepared for the undergraduates were as follows:

(1) Planning (thoughts about sections and details of the plan made for the current study)

(2) Implementation (thoughts about implementation of the plan in terms of each section (orientation, achievement, transfer and evaluation); thoughts about their role as an educational qualified staff)

The semi-structured interview instrument for the teachers was given to one primary teacher who did not participate in the study, as part of the pilot study. Likewise, the semi-structured interview instrument prepared for the undergraduates was piloted on two undergraduates who did not participate in the study. The pilot studies were conducted in order for the researcher to make the necessary modifications on the interview instruments to improve their readability, meaningfulness, appropriateness and so forth. However, the interview instruments were conducted without any problems. Then, the participant teachers were interviewed after the museum tour. Of the participant undergraduates, ten were randomly selected and interviewed. Furthermore, informal conversational interviews were conducted with all the participant teachers and all the participant undergraduates whenever it was possible.

Another data collection method used in the study was observations. The implementation was observed by the researcher during the museum tour. The researcher took notes, photographs and also made a video record.

Another instrument was used to gather data from the participant first graders to assess the permanence of their learning approximately one year later. For that purpose, a questionnaire including six multiple-choice questions and open-ended questions was developed by the researcher. The multiple-choice questions were as follows:

(1) What is the name of the museum?

(2) Which university campus is the museum at?

(3) Where is the original of the reproduction house used as the museum building?

(4) Whom did Atatürk live with at the original house?

(5) What was the name of the cow they lived with?

(6) What was the object under your envelope?

There was one open-ended question: 'How did you feel and what did you think about throughout the museum tour?' Lastly, the questionnaire asked students to explain what they learned from the museum tour by drawing a picture or writing their thoughts.

The questionnaire was examined by an expert from the field of primary education and piloted for understandability on two first graders who did not participate in the study. After taking the expert's opinion and the findings from the pilot test, necessary corrections were made to the questionnaire. On the basis of the expert opinion and pilot study, the first two questions which 
were open-ended questions were turned into multiple choice questions. Moreover, the question "Who lived in the original house?" was changed into the question "Whom did Atatürk live with in the original house?" Then the questionnaire was applied to the participant first graders 11 months after their trip to the museum in order to assess the permanence of their learning. The questionnaire was named as the student recall questionnaire.

\section{Data analysis of the study}

The data was analysed by using qualitative data analysis methods. The data obtained from the interviews, observations, and students' answers to the open-ended parts of the student recall questionnaire and the researcher's field notes were subjected to descriptive and content analysis whereas the data obtained from the students' answers to the multiple-choice questions of the student recall questionnaire were subjected to descriptive analysis. The data analysis was conducted by means of the following steps:

(1) Data coding

(1.1) Generating pre-codes and pre-categories

(1.2) Coding data by using pre-codes and pre-categories

(1.3) Generating last-codes and last-categories

(1.4) Coding data by using last-codes and last-categories

(2) Organising and reaching the findings

(3) Reporting conclusions from the findings

The formula of Miles and Huberman (1994) was used to determine the reliability of the research. The formula is as follows: Reliability $=$ Number of agreements/total number of agreements + disagreements (Miles \& Huberman, 1994).

The researcher of this study and an independent scholar coded the data independently, and the codes they agreed and disagreed with were counted. The following formula was then applied: Percentage of settlement $(\mathrm{P})=32 /(32+4) \times 100=88.8$

For the intercoder reliability via percentage agreement, a reliability percentage of at least $70 \%$ is required (Yildirim \& Şimşek, 2013). Thus, the intercoder reliability is satisfactory in the current study.

Moreover, Yıldırım and Şimşek (2013) expressed that there were precautions to be taken in order to ensure reliability and validity of qualitative research. In this respect, the precautions taken by the current study for external reliability purposes were explaining the researcher's role throughout the study; explaining the data collection procedure in detail. For the internal reliability of the study, the precautions taken by the study were presenting data gathered through observations and interviews, without interpretation via direct quotations; proving and supporting the results obtained from interviews and observations with each other; analyzing data by more than one researcher.

Yıldırım and Şimşek (2013) said that characteristics of qualitative research provided advantages and strategies for validity such as researcher's flexibility in terms of using new strategies, adding new questions to the interview, conducting new interviews not previously planned, using various data gathering methods, data gathering via face to face interviews and observations in the field. In this regard, the advantages and strategies were used for validity issue in the current study. 
Besides, data and participant triangulation was provided by gathering data via interviews, observations, student questionnaire and from teachers, undergraduates and students for reliability and validity of the current study.

\section{Findings}

From the data analysis, the findings were concluded under the categories planning, implementation and students' learning.

\section{Planning}

The analysis of the data gathered from the teachers' answers to the questions about their ordinary museum tour planning showed that all the teachers followed the same procedure for museum tours. They stated that there were three phases: before the tour, during the tour, after the tour. The phases defined by all the teachers as in the following excerpt:

We plan any museum tour in three phases: activities before the tour, activities during the tour and activities after the tour. We conduct interesting and motivational in-class activities related to the museum visit before the tour. During the tour we give information about the museum we are visiting and establish a connection between the museum and course subjects. Finally, we conduct in-class activities evaluating the tour after the museum tour (Teacher C).

The analysis of the researcher's field notes taken during the planning phase show that the researcher planned the museum tour using a planning form. Preparing multiple intelligencesbased activities would be conducted during the museum tour rather than in-class.

The researcher's plan comprised four sections, namely (1) instruction identity, (2) orientation, (3) achievement, and (4) transfer and evaluation. The analysis of the researcher's field notes showed that the researcher defined the sections and the activities of the sections in detail (see the title "The plan").

The analysis of the researcher's notes also showed that the researcher's instructional activities (second and third sections) were conducted in the museum.

The interviews conducted with the undergraduates about planning showed that most of them thought that museum tours should be carefully planned in terms of security and students' achievement. They emphasised that they would be primary school teachers and their target population would be 6-11-year-old children so permission from their families was mandatory. They emphasised not only official permissions, including from families, school and official departments, but also the safety of the children during the tour when talking about security, as in the following excerpt:

We will be the primary school teacher. We should take their safety into consideration at all times especially during activities out of school because our students would be 6-11year-old children. Therefore, planning is important for any instruction, but safety issues are more important when planning a museum visit, I think (U14).

The analysis of the undergraduates' answers to the interview questions also showed that they thought the plan was very easy to conduct; however, the preparation of the plan took a long time. Moreover, they stated that the planning stage took a long time but that made complex 
instructions easy:

I think if the teacher spends more time on planning and preparing a detailed plan, implementation will be easy. Moreover, museum tour is one of complex activities. I mean that it demands teachers to do many things such as taking permission, arranging transportation, and there is too much responsibility. Such planning lessens the burden on the teachers during the tour (U24).

Planning is the key for a museum tour, I think. One of the functions of the plan is its being simulation-like of the actual implementation. Therefore, the plan provided us with the opportunity to go over all the risky points of the museum tour in terms of children's security and to ensure a joyful teaching environment (U3).

\section{Implementation}

The analysis of the interviews conducted with the teachers showed that all the teachers thought that an educational unit including qualified staff was essential in museums to where primary schools organised a tour:

Like us, private primary schools frequently organise museum tours in Turkey. However, most of the museums in Turkey are inadequate to serve educational purposes. The implementation of your plan underlined the requirement by showing an ideal museum tour. The undergraduates behaved as if they were educational staff and we saw the students' reactions with our own eyes (TC).

The implementation of the plan revealed what a museum tour should be like for primary school students in terms of various aspects, I think. One of the aspects, the implementation indicates that if there are adequate educational staff in museums, museum tours having educational, instructional purposes will be successful. Most of the museums we visited do not have any educationally qualified staff, or there is a tourist guide for adults, so the museum tours are not educational (TD).

That was the first time we could visit the museum with our students without stress. Most of the museum tours, which we previously organised for instructional purposes turned into getting out of school and coming back safely. There were not any educational staff and so there was no instructional activity except our verbal explanations. Therefore, students were bored and did not achieve the purpose we planned. The implementation emphasises the importance of an educational department and staff in museums for primary school visitors (TB).

The analysis of the researcher's notes supported the teachers' thoughts, as in the following excerpts:

The students easily follow the undergraduates. They accept the undergraduates as their teachers. All of them call the undergraduates 'teacher' and follow the undergraduates who are responsible for their group. (21 November 2018, 11:02 a.m.)

The teachers seem to feel relaxed. Two teachers are talking with each other. One of them says, 'If there are these undergraduates in any museum tour, then the students really learn.' The other says, 'Yes it is true because students can ask their individual questions to the undergraduates and the students can be under control easily.' (Researcher notes, 21 November 2018, 11:14 a.m.)

Moreover, the findings from the interviews with the undergraduates indicated the importance of the educational qualified staff in the museums. One of the undergraduates said: 
I can see the importance of educational staff in museums from the perspectives of both staff and teacher because I am a prospective teacher, and my role is being a part of the educational staff in this study. Therefore, I can say that such staff should have teacher training in order to devise instructional activities, to interact with pupils effectively and they should also like conducting activities with children. From the perspective of my teacher role, I can say that if there were no staff like us, I don't think I would take my students on museum tours. It would seem impossible (U7).

Another finding was that the teachers thought that the orientation activity was the key point for such instruction. They thought that the implementation of the orientation section activity called the students' attention successfully. In this regard, one of the teachers said, 'The implementation of the first activity was very successful in terms of taking the students' attention' (TA). Another teacher said, 'I think the orientation section was very successful. Actually, if the orientation activity was well planned and implemented successfully, the rest of the implementation would go smoothly. like your implementation' (TE).

Like the teachers, most of the undergraduates emphasised the implementation of the orientation section, as in the following excerpts:

The implementation of the plan teaches me that the orientation section is the most important for both the planning and implementing process. When you were planning the orientation section, I did not understand why your study on the section took a long time. Now, I see why. I think a strong orientation activity makes the plan successful (U38).

Actually, the implementation showed us that the success of implementation depends on orientation. The orientation section is the heart of the implementation. Maybe we can say getting attention and motivation is the key because these are the purpose of orientation in the museum tour plan (U27).

Moreover, like the undergraduate U27, analysis of the researcher's notes indicated the importance of the orientation section in terms of motivation and capturing the students' attention. The following excerpt was taken from the researcher's field notes:

The implementation of the orientation is successfully completed. The students seem to be fascinatedly attracted by the envelopes. They say such statements like 'I am very curious', 'I cannot wait to come in', 'Let's get inside now.' (Researcher's note, 21 November 2018, 2:04 p.m.)

Furthermore, the data analysis related to the implementation of the achievement section of the plan showed that the students' interest was highest during this section. In this regard, three teachers expressed that they could observe the students when the students were visiting the museum with their group leader, so they realised that students did not become disinterested until the end of the museum tour. Also, they added that this was impressive for primary school children because usually they got bored and tired in the middle of museum tours. In this respect, teacher TC said:

According to my experiences, first graders generally get tired quickly when visiting museums, although they are only walking around museums and listening to me or a museum guide. But, during your implementation, the students visited the museum by walking, running, or reading and they showed no signs of tiredness. I think the achievement section activity satisfied their needs, as they played a game, moved around, touched objects, so they were not bored. 
Like the teacher TC, the teacher TB stated:

Actually, I did not expect the students' attention that originated from the orientation section to carry on into the achievement section. According to my experiences, first graders generally get tired and get bored quickly when visiting museums. This is because I have never experienced such well planned activities before.

The analysis of the interviews with the undergraduates also supported the findings about the students' high attention level during the achievement section, as in the following excerpts:

I had three first graders well in hand. I was nervous about managing them. Yet I realized that my fear was meaningless because they were interested in the objects in the museum during the achievement section of the implementation (U20).

I did not expect the first graders to have a high level of attention from the beginning to the end of the implementation. But it was the very case. They tried to listen and communicate with us and asked questions about the objects in the museum when they were leaving (U19).

Another finding about the implementation of the plan was that the students dealt not only with their objects but also with other objects in the museum. In this regard, one teacher said:

They stated the students were dealing with every object when looking for the photograph in their hands. One of them said, 'The envelopes captured their attention. Then the photographs let them examine most of the objects in the museum carefully. Also, I realised that the objects that the students were looking for were mostly on the last floor of the museum. That was a wise choice (TE).

The researcher notes also indicated the finding:

The students deal with all objects in the museum, except photographs and written documents hanging on the walls of the museum. Although the expected behaviour from them is to look for the photos of the objects in their hands, they examine all the objects in the museum. They continue to examine other objects even after finding the objects they are responsible for finding. (Researcher's notes, 21 November 2018, 2.25 p.m.)

Moreover, the undergraduates indicated that the students wanted to touch and ask many questions not only about the object they were responsible for finding, but also about the other objects in the museum:

I guided three students around the museum. All of them asked questions related to the other objects while looking for the objects they were responsible for finding and after finding them. They dealt with all the objects in the museum well (U5).

Furthermore, one of the findings was that the teachers, the undergraduates and the researcher thought that the students were physically and cognitively active during the implementation, as in the following excerpt:

The students were active in terms of the cognitive aspect when running between floors. It is not usual. When they are running, they generally focus solely on running. However, they were running to learn. It was interesting for me (TA). 
In most of our lessons, you have tried to teach us that teaching activities should be both mental and hands-on. In the implementation of the museum tour, I see what you mean. The students were walking, running, talking, and learning at the same time (U7).

All the students are on the move and also asking questions about the objects, looking for the objects they are responsible for finding, answering the questions about the objects. (Researcher's notes, 21 November 2018, 11:20 a.m.)

The last finding about the implementation was related to the transfer and evaluation section. The finding emerged from the analysis of the interviews conducted with the undergraduates and the researcher's field notes. The finding was that evaluation of the implementation did not let the implementers obtain quick results about their learning, as in the following excerpt:

We are used to arriving quickly at result in terms of evaluation as teachers or teaching candidates. In this respect, I can say that the evaluation part of the implementation did not let us to get quick results as we expected. On the other hand, it is not possible to know whether the students learnt or not that quickly (U17).

Although one of the findings was that the evaluation of the implementation did not let the implementers quickly obtain results about students' learning mastery, the researcher and the undergraduates received correct answers to their questions whenever possible during the implementation. The following excerpt was taken from the researcher's field notes:

The undergraduates and I ask some questions about the intended learning outcomes of the instruction to some of the students but not all during the implementation because of time limitations. The students we asked questions to give correct answers. The correctly answered questions are as follows:

Where is the object in the photo in the museum?

What is the object in the photo?

What did you learn about the object in the photo?

Where is Atatürk's original house?

Moreover, I wonder if their learning is permanent or not. Therefore, it should be tested after a while.' (Researcher's notes, 21 November 2018, 2:48 p.m.)

The undergraduates concurred with the researcher. Most of them stated that they asked some questions about the intended learning outcomes and the students answered these correctly; however, they were not sure whether the learning was permanent or not.

\section{Students' learning}

Actually, this category originated from the data gathering method at the end of the implementation. In other words, it was needed to gather data about students' learning permanence. Therefore, the questionnaire including multiple-choice and open-ended questions was applied to the students. The findings from the analysis of the data gathered from the questionnaire were presented under the category of students' learning.

The questionnaire was composed of six multiple-choice questions and one open-ended question. The questionnaire also asked students to explain what they learned from the museum tour by drawing a picture or writing their thoughts.

The students' answers to the multiple-choice questions were analysed as right, wrong and unanswered. Also, the number of students who participated in the museum tour was 120, but 
some of them left the school and went to another school over the course of the year. Because of that and other absences when the questionnaire was conducted, the number of students who took the questionnaire was 103. The findings are presented in the following table:

Table 2. The students' answers to the multiple-choice questions.

\begin{tabular}{lllll}
\hline Multiple-choice questions & $\begin{array}{l}\text { Number } \begin{array}{c}\text { of } \\
\text { correct answers }\end{array} \\
\text { What is the name of the museum? }\end{array}$ & $\begin{array}{l}\text { Number } \\
\text { wrong } \\
\text { answers }\end{array}$ & $\begin{array}{l}\text { Number of } \\
\text { blank } \\
\text { answers }\end{array}$ & Total \\
\hline $\begin{array}{l}\text { Which university campus is the museum at? } \\
\text { Where is the original of reproduction house used }\end{array}$ & 75 & 18 & 103 \\
as museum building? & 95 & 9 & 103 \\
Whom did Atatürk live with in the original house? & 64 & 39 & 103 \\
What was the name of the cow living with them? & 44 & 59 & 3 & 103 \\
What was the object under your envelope? & 100 & & 103 \\
\hline
\end{tabular}

The analysis of the students' answers to the open-ended question 'How did you feel and what did you think about throughout the museum tour?' showed that most of the students chose to explain their thoughts verbally. Some chose to explain by both drawing and writing, but none of them explained by only drawing. Moreover, the total number of students who gave an answer to the open-ended question was 81 .

The analysis of the students' answers to the question 'How did you feel throughout the museum tour?' indicated that 25 students were happy; 24 students felt good; 14 students were excited; and 10 students had fun. Moreover, 3 students wrote that they felt proud, and 2 students wrote that they were curious about the museum.

The analysis of the students' answers to the question 'What did you think about throughout the museum tour?' showed that 55 students thought about Atatürk. The second most common answer was that they thought about the people living at the house. This response was given by 17 students. Moreover, 5 students wrote that they thought how interesting Atatürk's belongings were. Furthermore, each of the following statements were written by students, 'I thought how they could find these items' (SC11): 'I thought of Atatürk's childhood' (SA13): 'I thought about the wars Ataturk won' (SA18): 'I thought once again about the importance of Atatürk for us' (SA22).

\section{Conclusion and discussion}

One of the findings stated under the category planning was that the participant teachers' ordinary museum tour was composed of activities actualised over three phases: before, during and after the museum tour. All the activities were conducted as in-class activities. On the other hand, the museum plan developed in the current study comprised four sections: instruction identity, orientation, achievement, and transfer and evaluation. The scope of the four sections included content, teachers' actions, and students' activities. The scope indicated by Ellis (2007) as basic decisions teachers need to make when planning. He expressed that planning for social studies tours includes basic decisions made by teachers in terms of content, activities of the teachers and the learners.

Furthermore, Ellis (2007) defined a good plan as a good map, which enables you to get to where you want to arrive at and that is flexible and open to possibilities along the way. When the current museum plan was discussed on the basis of Ellis's definition, it can be said that the museum plan was highly structured. However, one of the findings about the planning was that 
the participant undergraduates thought the planning phase took a long time, but this characteristic enabled them to conduct it easily. Also, they thought that the plan was as detailed as it should be because any museum tour demanded teachers to do many things, including taking permission, co-ordinating transportation and security of children, and devising attractive and instructive activities. Moreover, the current museum tour plan was developed taking existing situation (as-is and to-be) into consideration as much as possible, so the plan was detailed and structured. As a result, the plan developed for the current study was thought as exemplary for educationalists, including teachers and museums caring about their educational purpose.

When we look at the findings stated under the category of implementation, one of them was that the undergraduates and the teachers thought the role of the participant undergraduates showed that educationally qualified staff is vital for museum tours with primary school children. the necessity of such qualified staff has also been expressed in the literature. For example, Karadeniz and Okvuran (2018) indicated that the lack of qualified staff was one of the reasons for the slow progress of museum education practices in Turkey. The finding supported the necessity of qualified staff in museums. The findings showed that the participant teachers emphasised that the role of the undergraduates as qualified staff was one of the positive aspects of the current implementation. They expressed that the undergraduates had been qualified in both museum guidance and communication skills according to the characteristics of the target population (first graders). They stated that the characteristics of necessary qualified staff responsible for museum education in the museums should be like those of the undergraduates.

Moreover, one of the findings related with undergraduates was that their participation in the current study not only filled in the gap originated from the lack of qualified staff in the museum but also provided them with learning opportunities pertinent to museum education by acting, doing as prospect teachers. The findings indicated that their awareness about museum education increased, they learned how an effective and efficient museum tour was planned and implemented and also what possible obstacles they may face with. Supporting this result, Akman et al. (2015) also recommended that prospective teachers should have experiences regarding museum education practices for achieving effective and efficient museum education in Turkey.

Another finding, under the category of 'implementation,' was that both the teachers and the undergraduates thought the orientation activity was an attractive, instructive, and motivational activity so the students were highly motivated at the beginning of the tour. Also, the students' motivation continued throughout the tour. Because of that, they thought that the orientation activity as an introduction part of the implementation was the key point that determined the mode of the museum tour. The finding was supported by Ellis's saying about motivation. Ellis (2007) said that motivation was an influential instrument in the learning process. Moreover, the finding was supported by Taş's (2012) argument that students sustain learning motivation in museums thanks to learning by experience and observing. This is supported by one of the results of the current study.

One other finding, under the category of 'implementation,' was that the participants thought that activities conducted in the achievement phase satisfied the needs of the first graders in terms of playing games, moving, touching so their high level of active participant in the implementation carried on. The finding indicated Glover Frykman's (2009) sayings about museums. Glover Frykman (2009) stated that the museums, which was lively places where 
teachers and students can be active participants, offer an all-round learning experience environment rather than being places where a collection of artefacts or objects were displayed (Glover Frykman 2009).

One of the findings related with the 'implementation' was that there was desired activeness by learning; the desired activeness meant that students were active both cognitively and physically. Actually, the finding was the natural result of implementation on the basis of the multiple intelligences because the activities addressing multiple intelligences enabled learners to be active in terms of all domains of an individual. Besides, the instruction based on multiple intelligences make learners active in terms of multiple intelligences.

another finding under the category of implementation was related with the last section of the plan, transfer and evaluation section. It was due to that evaluation of the implementation did not let the implementers to obtain quick results about the students' mastery learning although the students correctly answered the questions related with their learning during the implementation. Actually, there is no quick result method about permanent learning in the field of education because permanent learning takes time, thusly entailing certain amount of time to pass.

The findings related with the category of students' learning showed that most of the students gave correct answers to the multiple-choice questions and also their expressions to the openended part of the questionnaire indicated that they learned what they were intended to learn. As was stated before, student recall questionnaire was applied to the students a year after the museum tour. Taking the application time and the students' correct answers into consideration, it can be stated that the students' learning was stored as an episodic memory in terms of information processing theory. Information processing theory is one of the leading theories that examine learning in terms of cognition (Maviş, 2015). The theory explains how information is processed, used, and stored in as memory. There are three types of memory: short-term memory, working memory and long-term memory (Muralikrishnan \& Sanjavan, 2009). In order to be able to talk about learned knowledge, it must have been stored in longterm memory having three parts: episodic, semantic, procedural memory (Engin, Calapoğlu, \& Gürbüzoğlu, 2008). The episodic memory is responsible for storing information about events that we have experienced in our lives. An example would be the memory of our first day at school (Engin et al., 2008). The information that was stored in the episodic memory can be remembered in detail, and it is accepted that the episodic memory is stronger than semantic memory (Engin et al., 2008). Thus, it can be stated that the current implementation would provide experience for the first graders and be stored in the episodic memory. In this regard, it would be said that such a planned museum tour can create the probability of students' learning being stored in the episodic memory by providing a memorable experience. Besides, the finding, about the students' recall questionnaire applied to the students a year after the museum tour, was similar to one result of the research conducted by Wollins et al. (1992). Their research result was that the students recalled the details of the museum trips where they participated in activities and in which they were assigned to be a leader or the demonstrator of a concept quite vividly even when the museum trips took place early in the academic year. Furthermore, Wolins et al. (1992) studied memory and put forward theories about how memory works and its functions. They also stated that some recent research has been conducted on children's "real world" (as opposed to laboratory) memories although early research studied the development of mnemonic strategies in a laboratory settings. Moreover, they emphasized museum visits were a productive "real world" event for the study of children's memory. 
As a conclusion of the study, the museum tour plan addressing multiple intelligences was successful on the basis of the teachers' and undergraduates' thoughts and also findings about students' learning. Moreover, with the museum tour plan developed in the research, an example for future museum tours has been presented. Furthermore, the study underlined the necessity and function of qualified personnel in museums. On the basis of the current study the suggestions for further studies and the field of education were as follows:

- Curriculum of undergraduate primary teacher education programs should include museum education as a compulsory course. The undergraduates should be prepared to be able to conduct effective and efficient museum tours with their students and also work as a member of educational department of museums.

- The courses related with instructional plan in the faculties of education should include museum tour designing in terms of making plans, implementing and evaluating the plan.

- Educational departments should be in museums and qualified educational staff should be occupied in the departments.

- The current study was conducted with $1^{\text {st }}$ grade primary school students, it could be useful to conduct studies with students from different age groups. Moreover, further research should be conducted to explore implications of teaching and learning in museum tours on students' motivation, learning and the students' learning memory.

\section{References}

Akman, B., Altınkaynak, Ş., Özen Altınkaynak, Ş., Ertürk, H., Ertürk Kara, H., \& Can Gül, Ş. (2015). Okul Öncesi Öğretmenlerinin Müze Eğitimine İlişkin Görüşleri [The Views of Preschool Teachers on Museum Education]. Uludağ Üniversitesi Ĕ̈itim Fakültesi Dergisi [Journal of Uludăg University Faculty of Education], 28 (1), 97-115. doi: 10.19171/uuefd.49876

Anderson, D., Piscitelli, B.,Weiver, K., Everett, M., \& Tayler, C. (2002). “Children's museum experiences: identifying powerful mediators of learning" Curator Museum Journal, 45 (3), 213-231. doi:10.1111/j.2151-6952.2002.tb00057.x

Ayaydın, A. (2017). Çoklu Zekâ Tabanlı Görsel Sanatlar Eğitiminde Bir Öğretim Yöntemi Olarak Müze Eğitimi [Museum Education as a Teaching Method in Multiple Intelligences Based Art Education]. Millî Eğitim Dergisi [Journal of National Education], $214 \quad$ (Spring):9-21. Retrieved from https://dergipark.org.tr/tr/pub/milliegitim/issue/36135/405914

Berg, B. L. (2001). Qualitative research methods for the social sciences (4 ${ }^{\text {th }} \mathrm{ed}$.), Boston: Allyn and Bacon.

Brualdi, A. (1998). Gardner's Theory. Teacher Librarian, 26(2):26-29.

Buyurgan, S. (2017). Verimli Bir Müze Ziyaretini Nasıl Gerçekleştirebiliriz? [How Can We Have an Efficient Museum Visit?]. Millî Eğitim Dergisi [Journal of National Education], 214 (Spring):317-343. Retrieved from https://dergipark.org.tr/tr/pub/milliegitim/issue/36135/405940

Dockett, S., Main, S., \& Kelly, L. (2011). Consulting young children: experiences from a museum. Visito Studies. 14 (1), 13-33. doi: 10.1080/10645578.2011.557626

Ellis, A. K. (2007). Teaching \&learning elementary social studies ( $8^{\text {th }}$ ed.), Boston: Pearson Publications.

Engin, A. O., Calapoğlu, M., \& Gürbüzoğlu, S. (2008). Uzun Süreli Bellek ve Öğrenme [Long-Term Memory and Learning]. Sosyal Bilimler Enstitüsü Dergisi [Journal of the 
Institute of Social Sciences], 2:251-262. https://www.kafkas.edu.tr/ dosyalar/sobedergi/file/02\%20(17).pdf

Erbay, F. (2017). Türkiye'de Müzecilik Eğitiminin Üniversitelerde Kurumsallaşması [Institutionalization of Museology Education in Turkish Universities]. Millî Eğitim Dergisi [Journal of National Education], 214 (Spring):105-122. Retrieved from https://dergipark.org.tr/tr/pub/milliegitim/issue/36135/405922

Erbay, M. (2017). Yeni Nesil Teknolojiler İle Müzelerde Eğitim [Education in Museums with Next Generation Technologies]. Millî Eğitim Dergisi [Journal of National Education], 214 (Spring):255-268. Retrieved from https://dergipark.org.tr/tr/pub/milliegitim/issue/36135/405935

Gardner, H. (1993). Multiple intelligences: The theory in practice, London: Sage.

Glover Frykman, S. (2009). Stories to Tell? Narrative Tools in Museum Education Texts. Educational Research, 51 (3): 299-319. doi: 10.1080/00131880903156898

Gouws, F. E. (2007). Teaching and Learning Through Multiple Intelligences in the Outcomes-Based Education Classroom. Africa Education Review, 4(2):60-74. doi:10.1080/18146620701652705.

Gregg, M. (1997). Seven Journeys to Map Symbols: Multiple Intelligences Applied to Map Learning. Journal of Geography, 96(3): 146-152. doi: 10.1080/00221349708978776

Karadeniz, C.,. Artar, A. M., \& Çakır İlhan, A. (2015). Contemporary Approaches and Museum Educator within the Context of New Museology. Ankara University Journal of Faculty of Educational Sciences (JFES,) 48 (2):203-226. doi: 10.1501/Egifak_0000001371.

Karadeniz, C., \& Okvuran, A. (2018). Museum Education in Turkey from the Proclamation of the Republic to the Present: Historical Development and Future Projections. Millî Folklor [International and Quarterly Journal of Cultural Studies], 30 (118):101-113.

Maviş, F. Ö. (2015). Bilgiyi işleme kuramı [Information processing theory]. In M. Arslan (Ed.), Öğrenmenin nörofizyolojisi ve ögretimde yeni yaklaşımlar [Neurophysiology of learning and new approaches in teaching]. (29-48). Ankara: An1 Yayınlar1.

Mentiş Taş, A. (2015). Primary-grade teacher candidates' views on museum education. USChina Education Review A, 6, 606-612.

Mills, G. E. (2000). Action research: a guide for the teacher researcher, New Jersey: Prentice Hall.

Miles, M. B., \& Huberman, A. M. (1994). Qualitative data analysis: An expanded sourcebook ( $\left.2^{\text {nd }} e d\right)$, Thousand Oaks, CA: Sage.

Muralikrishnan, T.R., \& Sanjayan, T. S. (2009). Is There A Teacher in This Class? Information Processing, Multimedia and Education. Acta Didactica Napocensia, 2 (2), 79-84. https://eric.ed.gov/?id=EJ1052540

Nolen, J. L. (2003). Multiple Intelligences in the Classroom. Education, 124(1):115-120.

Shearer, C. B. (2020). Multiple Intelligences in Gifted and Talented Education: Lessons Learned from Neuroscience After 35 Years. Roeper Review, 42(1):49-63.doi: 10.1080/02783193.2019.1690079.

Sternberg, R. J. (2003). Cognitive psychology, Belmont: Thomson Wadsworth.

The Ministry of Culture and Tourism. "Museums Internal Services Regulation." June 22, 2020. https://teftis.ktb.gov.tr/yazdir?85452970A0B1DECFE1BF670A7A55E6AC

Wolins, I. S., Jensen, N., Ulzheimer, R. (1992). Children's memories of museum field trips: a qualitative study. The Journal of Museum Education, 17 (2), 17-27.

Yıldırım, A. \& Şimşek, H. (2013). Sosyal Bilimlerde Nitel Araştırma Yöntemleri (9. baskl) [Qualitative Research Methods in Social Sciences. (9 ${ }^{\text {th }}$ ed.)]. Ankara: Seçkin Pub. 